\title{
REVIEW
}

\section{PIK3CA mutations in breast cancer: reconciling findings from preclinical and clinical data}

\author{
Dimitrios Zardavas', Wayne A Phillips ${ }^{2,3}$ and Sherene Loi ${ }^{3,4^{*}}$
}

\begin{abstract}
PIK3CA mutations represent one of the most common genetic aberrations in breast cancer. They have been reported to be present in over one-third of cases, with enrichment in the luminal and in human epidermal growth factor receptor 2-positive subtypes. Substantial preclinical data on the oncogenic properties of these mutations have been reported. However, whilst the preclinical data have clearly shown an association with robust activation of the pathway and resistance to common therapies used in breast cancer, the clinical data reported up to now do not support that the PIK3CA mutated genotype is associated with high levels of pathway activation or with a poor prognosis. We speculate that this may be due to the minimal use of transgenic mice models thus far. In this review, we discuss both the preclinical and clinical data associated with PIK3CA mutations and their potential implications. Prospective clinical trials stratifying by PIK3CA genotype will be necessary to determine if the mutation also predicts for increased sensitivity to agents targeting the phosphoinositide 3-kinase pathway.
\end{abstract}

\section{Introduction}

Phosphoinositide 3-kinases (PI3Ks) comprise a family of lipid kinases, discovered in the 1980s, that are responsible for mediating important biological functions such as cell survival, differentiation and proliferation [1]. In breast cancer, mutations of the PIK3CA gene, which encodes the p110 $\alpha$ catalytic subunit of PI3K, are highly frequent $(2,257 / 9,095=24.82 \%$ according to the Catalogue of somatic mutations in cancer [2]), have been shown to be oncogenic, and are likely to represent important events in the initiation and progression of breast cancer. However, several characteristics of PIK3CA mutations in

\footnotetext{
* Correspondence: sherene.loi@petermac.org

${ }^{3}$ Division of Cancer Medicine and Research, Peter MacCallum Cancer Centre, St Andrews Place, East Melbourne, Victoria 3002, Australia

Full list of author information is available at the end of the article
}

breast cancer have been observed, including a strong association with expression of the estrogen receptor (ER), a lack of an association with robust activation of the classical PI3K pathway, as well as a relatively good prognosis for patients with mutations compared with their wild-type counterparts. These features make it difficult to understand the functional and clinical relevance of PIK3CA mutations in breast cancer at present. In this article we review and summarize the preclinical and clinical data in breast cancer in an attempt to reconcile these findings.

\section{Background}

Based on distinct structural characteristics and substrate specificity, PI3Ks can be divided into three classes, I to III. Class I can be further subdivided into class IA and IB kinases, with class IA activated by receptor tyrosine kinases (RTKs), G protein coupled receptors and other oncogenes such as RAS, and class IB activated exclusively by G protein coupled receptors [3]. Class IA PI3Ks represent the most extensively studied subclass, with implications in human carcinogenesis [3]. They are heterodimers consisting of a catalytic (p110) and a regulatory (p85) subunit, with the latter stabilizing the former in quiescent cells and suppressing PI3K activity. There are three different isoforms of the p110 subunit in mammals, $\mathrm{p} 110 \alpha, \mathrm{p} 110 \beta$ and $\mathrm{p} 110 \delta$, transcribed from the genes PIK3CA, PIK3CB and PIK3CD, respectively, and three isoforms of the p 85 subunit, p $85 \alpha, \mathrm{p} 55 \alpha$ and $\mathrm{p} 50 \alpha$, deriving from three genes PIK3R1, PIK3R2 and PIK3R3, respectively [4]. The p110 $\alpha$ subunit consists of five domains: an amino-terminal domain termed adaptorbinding domain, a Ras-binding domain, a C2 domain, a helical domain and a kinase catalytic domain [5]. The p85 $\alpha$ regulatory subunit also contains five domains: an amino-terminal SH3 domain, a Rho-GAP domain and two Src homology 2 ( $\mathrm{SH} 2$ ) domains (one towards the amino terminus, $\mathrm{nSH} 2$, and one carboxy-terminal, $\mathrm{cSH} 2$ ), separated by an inter-SH2 (iSH2) domain [5]. 
Upon growth factor stimulation p85 binds through its SH2 domains to phospho-motifs of RTKs, relieving its inhibitory effect over p110 and mediating the recruitment of PI3K to the plasma membrane. The activated p110 subunit catalyses the conversion of phosphatidylinositol-4, 5-bisphosphate to phosphatidylinositol-4,5-trisphosphate, which subsequently provides a docking site for the pleckstrin homology domain-containing proteins PDK1 and AKT [6]. The next step is a dual phosphorylation of AKT (on T308 and S473 residues), resulting in its activation and a subsequent intracellular cascade of phosphorylation of other proteins, including mammalian target of rapamycin (mTOR) [7]. The final functional outcome of this cascade of intracellular events is the induction of the multiple biologic effects of the PI3K/AKT/mTOR signaling pathway.

Activation of the PI3K/AKT/mTOR pathway has been demonstrated in all human cancers, with different aberrations variably affecting its different molecular components. In the setting of breast cancer, this represents the most commonly deregulated signaling pathway, with alterations that can be summarized as follows: i) overexpression of PI3K-activating RTKs; ii) inactivating events of negative PI3K pathway regulators (that is, phosphatase and tensin homologue (PTEN) and inositol polyphosphate 4-phosphatase type II); and iii) activating events of PI3K pathway components and/or positive regulators. Mutations of the PIK3CA gene, belonging to the third category, represent the most frequently reported molecular alterations of the PI3K signaling pathway in breast cancer.

\section{Preclinical data}

\section{Oncogenicity of PIK3CA mutations}

PIK3CA has been reported to be mutated frequently in human cancer, particularly in common cancer types such as breast, colorectal, endometrial and prostate [8-16]. This makes it an attractive target for therapeutic intervention. In the setting of breast cancer, PIK3CA mutations are extremely common, second only to TP53 mutations [17-20]. The mutations display a non-random distribution, clustering within the helical domain (exon 9, commonly E542 and E545) and the kinase domain (exon 20, commonly H1047). When first reported, the presence of these hotspot' positions strongly implied that the mutant protein would be associated with increased kinase activity and oncogenic properties [21]. Such clustering of mutations in specific domains has been noted in other activating oncogenes, such as BRAF, RAS and EGFR. Interestingly, the non-class I PI3Ks have not been reported to be associated with oncogenic mutations.

The function of mutant PIK3CA protein compared with the wild type has been characterized in both human cancer cell lines and human mammary epithelial cells, mainly using gene targeting approaches [22-24]. Several investigators have reported that the mutation was strongly associated with AKT activation, growth factorindependent cell proliferation, resistance to apoptosis, as well as increased invasion and cell migration. Biochemical inhibition of the PI3K pathway was found to be effective in reversing these properties, particularly in PIK3CA mutant cell lines $[22,23,25,26]$. In human mammary epithelial cell lines, the two most common mutant alleles (H1047R and E545K) were found to activate PI3K signaling and could easily form tumors in nude mice $[24,26]$. Resistance to paclitaxel was also demonstrated [23]. Interestingly, significant increases in tumor angiogenesis have also been reported to be associated with oncogenic PIK3CA activity [26].

Differences between the helical and kinase domain mutants have also been extensively investigated. The data suggest that there are at least two different mechanisms by which mutant $\mathrm{p} 110 \alpha$ can activate PI3K signaling. These differences are also supported by structural studies. The helical domain mutants require RAS binding for transformation and are independent of p85, whereas the H1047R mutant depends on p85 binding $[27,28]$. In another study, helical domain mutants produced a more aggressive phenotype than kinase domain mutants with regard to cellular motility and enhanced extravasation [29]. This study, however, used the MDAMB-231 breast cancer cell line, which is known to be RAS mutant and ER-negative, so it is conceivable that the helical domain mutant could have synergized with these features. It is unclear how to extrapolate these data when, in breast cancer, PIK3CA mutations are strongly associated with an ER-positive phenotype and RAS mutations are extremely rare [29]. As a possible explanation for the phenotypic differences between the various PIK3CA mutations, a recent study has reported that helical domain but not kinase domain mutants acquire the capability to interact with IRS1, thus enhancing its ability to associate with the cellular membrane and subsequently activate the pathway [30]. This study highlighted that loss of p85 was not enough to result in growth factor-independent activity of p110 $\alpha$ [30] and proposes a mechanistic reason for the differences seen between the helical and kinase domain mutations.

Crystal structure and biochemical analyses have also helped elucidate how different oncogenic PIK3CA mutations can change the PI3K architecture and promote oncogenicity dependent on the location of the mutated domain $[31,32]$. Mutations of the catalytic p110 $\alpha$ subunit cluster around the activation loop involved in substrate recognition. In contrast, the helical domain mutants disrupt the interface between $\mathrm{p} 110 \alpha$ and $\mathrm{p} 85 \alpha$, which likely increases the activity of the enzyme [31,32]. Besides these commonly occurring 'hotspot' PIK3CA mutations, rarer PIK3CA mutations on the $\mathrm{C} 2$ and RBD domains 
have also been found in human cancers. These have mostly been found to also be oncogenic, although due to different mechanisms. For example, mutations in the $\mathrm{C} 2$ domain are thought to facilitate $\mathrm{p} 110 \alpha$ localizing to plasma membrane by increasing the positive surface charge of this domain [33].

Interestingly, in breast cancer, the clinical difference between helical and kinase domain mutants is subtle [34,35]. Double mutants, or cases with two different PIK3CA mutations, have also been observed in breast cancer, albeit infrequently. There seems to be a higher incidence of PIK3CA mutations, particularly the helical domain mutants, in lobular cancer versus ductal invasive breast cancers (lobular 30.8\% versus ductal 24.4\%; $P=$ 0.14) [34]. Also of note is that the common breast cancer cell lines used in preclinical experiments (MCF7 and T47D) contain a PIK3CA mutation (helical and kinase domains, respectively). These cell lines strongly express $\mathrm{ER}$, are of the 'luminal A' phenotype and are sensitive to treatment with the hormonal agent tamoxifen [36].

\section{PIK3CA mutations and therapy resistance in vitro}

PIK3CA mutations have been reported to be associated with resistance to human epidermal growth factor receptor 2 (HER2) and endocrine therapies in a number of preclinical cell line and xenograft models. In the setting of HER2-positive breast cancer, several preclinical studies have reported that PIK3CA mutations are associated with resistance to HER2 blockade with trastuzumab $[37,38]$. Another study also confirmed that these mutations could mediate resistance to trastuzumab, although the E545Kand H1047R-HER2 overexpressing breast cancer cell lines were sensitive to GDC-0941, a pan-PI3K inhibitor [39]. PI3K signaling pathway activation has also emerged as a molecular mediator of endocrine resistance in the setting of luminal breast cancer, with multiple lines of evidence supporting this notion [40-43]. Several studies have demonstrated a clear synergy between endocrine treatment and various PI3K blocking agents [41-44].

\section{Mouse models of PIK3CA mutations}

Generation of transgenic mouse models can help us better understand the function of PIK3CA mutation in vivo, its contribution to mammary tumorigenesis, as well as its contribution to resistance of commonly used therapies.

Several different types of Pik3ca-driven mouse models of breast cancer have been reported (Table 1) [45]. Interestingly, in one study using the MMTV-Cre Pik3ca ${ }^{\mathrm{H} 1047 \mathrm{R}}$ model high lethality (75\%) was observed in mice younger than 4 months due to non-mammary tumor-related causes [46]. Leakiness of the mouse mammary tumor virus (MMTV) promoter resulting in harmful $P i k 3 c a^{\mathrm{H} 1047 \mathrm{R}}$ expression in tissues other than mammary gland was thought to be the cause. Similarly, another study with MMTV-Cre
$P i k 3 c a^{\mathrm{H} 1047 \mathrm{R}}$ mice also showed a high lethality rate for reasons other than mammary tumors (43\%), questioning the utility of a broad transgenic method [47]. The other approach has been to create endogenous levels of Pik3$c a^{\text {H1047R }}$ using a knock-in system under the control of a native promoter (combined with MMTV-Cre) [48,49]. These models are created to induce physiological expression of the mutant protein in the mammary gland only.

All the Pik3ca-driven models have produced mammary tumors of varying histologies in contrast to single histology mouse models such as Neu, Myc and the polyoma middle- $\mathrm{T}$ antigen. These included fibroadenomas, adenocarcinomas, adenosquamous carcinomas, sarcomas and spindle cell tumors. These tumors expressed $\mathrm{ER} \alpha$, as well as basal and luminal cytokeratin markers. Transgenic models resulted in far shorter latency periods, probably due to the overexpression of the mutant and wild-type protein induced by the exogenous promoters. In contrast, the knock-in models, which produce endogenous levels of the mutant protein, had extremely long latencies before the development of tumors, which was shorter in parous versus nulliparous mice, suggesting that pregnancy significantly accelerated Pik3ca mutation-mediated mammary oncogenesis. Notably, in one knock-in model, a significant increase in cell number in the ducts (hyperplasia), as well as the number of surrounding stromal cells, was observed [48]. These cells represented expansion of the luminal progenitor population, which demonstrated enhanced colony size and formation, though without signs of classical PI3K pathway activation [48]. The lack of activation of the pathway (pAKT and pS6) seems to more closely replicate the human observations. Overall, metastases have been rarely reported, perhaps suggesting that additional genetic alterations are needed. Two studies reported reduced latencies as a result of synergism between PIK3CA H1047R and p53 mutations [47,49]. Another study reported that PIK3CA mutant tumors could recur using both PI3K-dependent and -independent mechanisms or c-MET and MYC overexpression, respectively, the latter leading to resistance to a PI3K inhibitor [50].

These data highlight the importance of Pik3ca mouse models in contributing to a better understanding of PIK3CA mutant pathogenesis and breast cancer development, as well as investigating resistance mechanisms to commonly used therapeutics. They will provide a better understanding of mutation-related cell-extrinsic mechanisms as the tumors grow in the setting of intact immune systems and surrounding stroma. In vivo mouse models may perhaps also clarify some of the counterintuitive results that have been observed in the clinical setting, which we will discuss below. Phenotypic differences between knock-in and transgenic models are also evident, and clinical observations will eventually validate 
Table 1 Genetically engineered mouse models of PIK3CA mutations

\begin{tabular}{|c|c|c|c|c|c|c|}
\hline Study & Mouse model & $\begin{array}{l}\text { Transgenic versus } \\
\text { knock-in }\end{array}$ & $\begin{array}{l}\text { Inducible versus } \\
\text { non-inducible }\end{array}$ & Penetrance & Tumor latency & Histology \\
\hline \multirow{3}{*}{$\begin{array}{l}\text { Tikoo et al. } \\
{[48]}\end{array}$} & \multirow{3}{*}{$\begin{array}{l}\text { MMTV-Cre } \\
\text { Pik3ca }^{\text {H1047R }}\end{array}$} & \multirow[t]{3}{*}{ Site-specific } & \multirow[t]{3}{*}{ Non-inducible } & \multirow[t]{3}{*}{$100 \%$} & \multirow{2}{*}{$\begin{array}{l}\text { Nulliparous mice: } \\
484 \text { days }\end{array}$} & Fibroadenoma (45\%) \\
\hline & & & & & & Adenosquamous carcinoma (10\%) \\
\hline & & & & & $\begin{array}{l}\text { Biparous mice: } \\
393 \text { days }\end{array}$ & Osteosarcoma (2.5\%) \\
\hline \multirow{3}{*}{$\begin{array}{l}\text { Yuan et al. } \\
\text { [49] }\end{array}$} & \multirow{3}{*}{$\begin{array}{l}\text { MMTV-Cre } \\
\text { Pik3ca }{ }^{\text {H1047R }}\end{array}$} & \multirow[t]{3}{*}{ Site-specific } & \multirow[t]{3}{*}{ Non-inducible } & \multirow[t]{3}{*}{ NR } & \multirow{2}{*}{$\begin{array}{l}\text { Nulliparous mice: } \\
492 \text { days }\end{array}$} & Fibroadenoma (76.9\%) \\
\hline & & & & & & Adenocarcinoma (15.4\%) \\
\hline & & & & & $\begin{array}{l}\text { Multiparous mice: } \\
465 \text { days }\end{array}$ & Spindle cell neoplasia (7.7\%) \\
\hline \multirow{6}{*}{$\begin{array}{l}\text { Liu et al. } \\
\text { [50] }\end{array}$} & \multirow{6}{*}{$\begin{array}{l}\text { MMTV-rtTA TetO- } \\
\text { Pik3ca }^{\text {H1047R }}\end{array}$} & \multirow[t]{6}{*}{ Transgenic } & \multirow{6}{*}{$\begin{array}{l}\text { Inducible } \\
\text { (doxycycline) }\end{array}$} & \multirow[t]{6}{*}{$95 \%$} & \multirow[t]{6}{*}{7 months } & Solid (33\%) \\
\hline & & & & & & Acinar (8\%) \\
\hline & & & & & & Glandular (5\%) \\
\hline & & & & & & Papillary (12\%) \\
\hline & & & & & & Squamous metaplasia (15\%) \\
\hline & & & & & & Mixed (28\%) \\
\hline \multirow{8}{*}{$\begin{array}{l}\text { Adams et al. } \\
{[47]}\end{array}$} & \multirow{4}{*}{$\begin{array}{l}\text { MMTV-Cre }{ }^{\text {NLST }} \\
\text { Pik3ca }^{\text {H1047R }}\end{array}$} & \multirow[t]{4}{*}{ Transgenic } & \multirow[t]{4}{*}{ Non-inducible } & \multirow[t]{4}{*}{ NR } & \multirow[t]{4}{*}{5 months } & Adenosquamous carcinoma ( $51 \%)$ \\
\hline & & & & & & Adenomyoepithelioma (45\%) \\
\hline & & & & & & Spindle cell neoplasia (1\%) \\
\hline & & & & & & $\begin{array}{l}\text { Poorly differentiated } \\
\text { adenocarcinoma (3\%) }\end{array}$ \\
\hline & \multirow{4}{*}{ 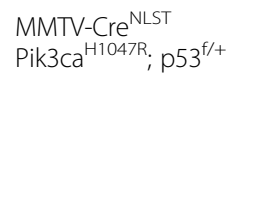 } & \multirow[t]{4}{*}{ Transgenic } & \multirow[t]{4}{*}{ Non-inducible } & \multirow[t]{4}{*}{ NR } & \multirow[t]{4}{*}{$<5$ months } & Adenosquamous carcinoma (51\%) \\
\hline & & & & & & Spindle cell/EMT tumor (33\%) \\
\hline & & & & & & Radial scar lesion (10\%) \\
\hline & & & & & & $\begin{array}{l}\text { Poorly differentiated } \\
\text { adenocarcinoma (5\%) }\end{array}$ \\
\hline \multirow[t]{5}{*}{$\begin{array}{l}\text { Meyer et al. } \\
{[46]}\end{array}$} & \multirow[t]{4}{*}{ WAPi-Cre Pik3ca ${ }^{H 1047 R}$} & \multirow[t]{4}{*}{ Transgenic } & \multirow[t]{4}{*}{ Non-inducible } & NR & $\begin{array}{l}\text { Nulliparous mice: } \\
219 \text { days }\end{array}$ & $\begin{array}{l}\text { Adenosquamous carcinoma } \\
(54.6 \%)\end{array}$ \\
\hline & & & & & & Adenomyoepithelioma (22.7\%) \\
\hline & & & & & $\begin{array}{l}\text { Parous mice: } \\
140.3 \text { days }\end{array}$ & $\begin{array}{l}\text { Adenocarcinoma with squamous } \\
\text { metaplasia }(13.6 \%)\end{array}$ \\
\hline & & & & & & Adenocarcinoma (9.1\%) \\
\hline & $\begin{array}{l}\text { MMTV-Cre } \\
\text { Pik3ca }{ }^{\text {H1047R }}\end{array}$ & Transgenic & Non-inducible & $25 \%$ & $\begin{array}{l}\text { Nulliparous mice: } \\
214 \text { days }\end{array}$ & Adenomyoepithelioma (100\%) \\
\hline
\end{tabular}

EMT epithelial-mesenchymal transition, MMTV mouse mammary tumor virus, NR not reported.

which model more closely represents human PIK3CA mutated breast cancer.

\section{Clinical data}

PIK3CA mutations, prognosis and treatment efficacy in breast cancer

The clinical relevance of PIK3CA mutations in newly diagnosed breast cancer disease has been extensively investigated. Surprisingly, PIK3CA mutations have been associated with good prognostic clinico-pathological features in breast cancer. These include positive expression of ER, smaller tumor size and low histological grade [51-54].

Whilst smaller studies initially reported inconsistent prognostic results, the larger studies now emerging seem to be trending in the same direction [40]. The largest published study evaluated PIK3CA genotype from 687 tumor samples from patients enrolled in the FinHER prospective, phase III clinical trial $[34,55]$. PIK3CA mutant compared with wild-type patients were noted to have a better prognosis in the first 3 years, which disappeared with longer follow-up [56]. Consistent with these results, a single center retrospective cohort analysis of 590 patients also reported that PIK3CA mutations were associated with significantly better clinical outcomes [51]. A retrospective pooled analysis of four neoadjuvant endocrine therapy breast cancer trials involving 278 women did not find that PIK3CA mutations were associated with endocrine therapy resistance [57]. Recently, published in abstract form, PIK3CA genotyping of the TEAM adjuvant endocrine study found a mutation 
frequency of $39.8 \%(1,702 / 4,272)$ in post-menopausal patients with ER-positive tumors [35]. Again, significantly better survival was observed for the PIK3CA mutant breast cancers: hazard ratio 0.76 (95\% confidence interval 0.63 to 0.91$), P=0.003$.

PIK3CA mutations have been reported in ductal carcinoma in situ [58], suggesting that they are an early event, consistent with the knock-in mouse models. However, it seems that in breast cancer the mutation is not associated with high levels of PI3K pathway activation such as increased phosphorylated AKT (S473) and pS6 [18,59]. A genomic study reported that a gene signature developed from PIK3CA mutant human breast cancers was associated with low mTORC1 output and high ESR1 signaling [44]. In contrast, PIK3CA mutant cell lines were associated with high levels of activation in vitro. This observation further supports the use of transgenic knock-in mouse models rather than breast cancer cell lines to investigate the functional effects of PIK3CA mutations. These data suggest several possibilities. Perhaps, similar to PTEN deficiency, high levels of PI3K pathway activation could be detrimental to the cell (that is, cause senescence); therefore, strong negative feedback is active in containing pathway activation until a 'second hit' disables this [60]. Alternatively, PIK3CA mutations may be weak activators of the PI3K pathway, due to the requirement for plasma localization and/or other activating factors, and require another hit(s) for full activation. We also speculate that the mutation may itself activate estrogen signaling given the strong cross-talk that exists between the two pathways. This would result in patients with PIK3CA mutations responding well to current endocrine therapies, which may explain the clinical observations.

With regards to HER2-positive disease, a number of single arm, cohort, single institutional series have suggested an association between the PI3K signaling pathway and trastuzumab and/or lapatinib resistance [61-65]. The majority of these have included PTEN loss or PIK3CA mutations to define activated PI3K pathway. The only data evaluating differences in treatment benefit from a randomized study did not observe that PIK3CA mutations were significantly associated with resistance to trastuzumab [56]. In fact, the opposite was observed. In contrast, in metastatic HER2+ disease, PIK3CA mutations have been associated with poor prognosis. Results from a retrospective biomarker analysis in the CLEOPATRA study, a phase III study assessing the trastuzumab, pertuzumab and docetaxel triplet versus trastuzumab, docetaxel and placebo in first-line treatment of HER2-positive metastatic breast cancer [66], were recently presented. PIK3CA genotype from the primary (not metastatic) tumor was found to be prognostic, with patients bearing a PIK3CA mutation having a worse clinical outcome $(P=0.0001)$ [67]. Interestingly, PIK3CA mutations did not predict for resistance to any type of HER2 blockade in this study, with significant clinical benefit of the triple combination of trastuzumab, pertuzumab and docetaxel persisting irrespective of its mutational status [67]. Further data will be required to confirm these findings. A more complete understanding of the genetic composition of these tumors, both primary and metastatic, will also be beneficial. It could be that, in the advanced setting, dual HER2 amplification and PIK3CA mutation results in complete and robust activation of the PI3K pathway.

Hence, it is becoming clearer that PIK3CA mutations are associated with better outcomes in primary ERpositive disease. Generating firm associations with prognosis and clinical relevance could perhaps be achieved by a pooled analysis of all available data. This could result in PIK3CA genotype being integrated into clinical decision-making. However, its relevance in advanced disease is unclear and may be different from primary disease. However, the most interesting question remains: will a PIK3CA mutation predict for increased sensitivity to a PI3K inhibitor?

\section{Therapeutic targeting of PIK3CA mutated breast cancer}

Currently, an abundance of targeted compounds are under clinical development targeting several components of the PI3K signaling pathway (Figure 1, Table 2) [68]. Preclinical evidence demonstrates sensitivity of PIK3CA mutated breast cancer cells to PI3K blocking agents $[69,70]$ and, with $p 110 \alpha$ isoform-selective inhibitors being under clinical development, there is the promise for more potent target inhibition coupled with a milder toxicity profile [71]. Whilst the clinical development of those agents is still too preliminary for any definitive conclusions to be drawn, early data from phase I clinical trials do not support a strong association of antitumor activity by pan-class I PI3K blocking agents with PIK3CA genotype [72-74]. However, recent early results using the $\mathrm{p} 110 \alpha$ isoform-selective inhibitors look promising in heavily pretreated PIK3CA mutant breast cancers [72]. BOLERO-2 was a phase III trial that randomized 724 patients with ER-positive metastatic breast cancer resistant to nonsteroidal aromatase inhibitors to receive exemestane and everolimus (an mTORC1 inhibitor) or placebo. The outstanding results have led to the registration of everolimus in this setting [75]. A biomarker analysis using available primary tumor from 227 (31\%) patients from this study and a Foundation Medicine 182 cancer-mutation panel found PIK3CA was the most frequently mutated gene among the cases analyzed (48\%). However, it was not found to be predictive, with similar treatment benefit derived from the everolimus plus exemestane therapy among PIK3CA mutated and wild-type breast cancer patients [76]. Hence, the 


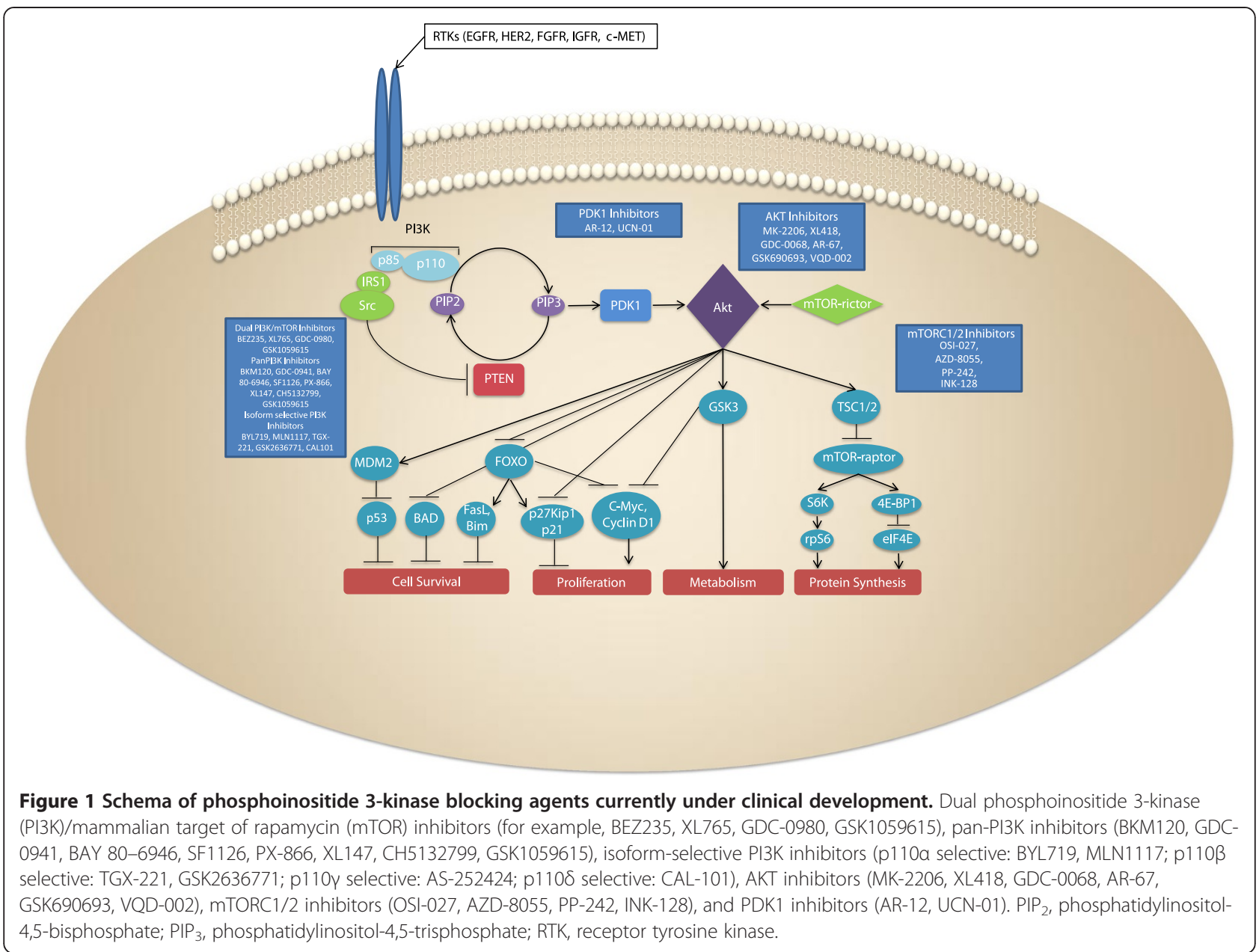

Table 2 Ongoing clinical trials recruiting breast cancer patients with PIK3CA mutations

\begin{tabular}{|c|c|c|c|c|}
\hline Agent & Class & Trial & Description & Patients (n) \\
\hline \multirow[t]{2}{*}{ BYL719 } & $\begin{array}{l}\text { a-Selective PI3K } \\
\text { inhibitor }\end{array}$ & $\begin{array}{l}\text { Phase I } \\
\text { (NCT01219699) }\end{array}$ & Dose escalation in combination with fulvestrant & $\begin{array}{l}\text { Postmenopausal women with } \\
\text { MBC (160) }\end{array}$ \\
\hline & & $\begin{array}{l}\text { Phase Ib/II } \\
\text { (NCT01708161) }\end{array}$ & Dose escalation in combination with AMG479 & Advanced solid tumors (70) \\
\hline BKM120 & $\begin{array}{l}\text { Pan-PI3K } \\
\text { inhibitor }\end{array}$ & $\begin{array}{l}\text { Phase I/II } \\
\text { (NCT01589861) }\end{array}$ & Dose escalation in combination with lapatinib & $\begin{array}{l}\text { HER2-positive, trastuzumab- } \\
\text { resistant MBC (106) }\end{array}$ \\
\hline \multirow[t]{2}{*}{ MK2206 } & AKT inhibitor & $\begin{array}{l}\text { Phase II } \\
\text { (NCT01277757) }\end{array}$ & Safety and efficacy of MK2206 monotherapy & Advanced breast cancer (40) \\
\hline & & $\begin{array}{l}\text { Phase II } \\
\text { (NCT01776008) }\end{array}$ & $\begin{array}{l}\text { Safety and efficacy of MK2206 and anastrozole with or without } \\
\text { goserelin in the neoadjuvant setting }\end{array}$ & $\begin{array}{l}\text { ER-positive breast cancer, } \\
\text { stage II to IIIC (87) }\end{array}$ \\
\hline \multirow[t]{2}{*}{ AZD5363 } & AKT inhibitor & $\begin{array}{l}\text { Phase I } \\
\text { (NCT01226316) }\end{array}$ & Dose escalation & $\begin{array}{l}\text { Advanced solid tumors and } \\
\text { MBC (107) }\end{array}$ \\
\hline & & $\begin{array}{l}\text { Phase I } \\
\text { (NCT01625286) }\end{array}$ & Dose escalation in combination with paclitaxel & ER-positive MBC (110) \\
\hline
\end{tabular}


optimal PI3K pathway inhibition strategy in the setting of PIK3CA mutations also remains to be determined.

The only way to definitively determine the prognostic and predictive relevance of PIK3CA genotype in breast cancer will be through prospectively defined, upfront stratification in clinical trials. The 'NeoPHOEBE' trial (ClinicalTrials.gov study NCT01816594 [77]) is one such trial. This study will evaluate if the addition of BKM120, an oral pan-class I PI3K inhibitor, to trastuzumab improves response rates in HER2-overexpressing breast cancer. Eligible patients will undergo upfront PIK3CA genotyping as the trial will essentially have two identical cohorts in order to ensure that the PIK3CA mutant population is adequately powered. This trial will attempt to provide answers to the following important questions: i) is PIK3CA mutated, HER2-positive disease associated with trastuzumab resistance compared with wild type (prognostic implications), and ii) is PIK3CA mutation compared with wild-type associated with an increased response rate in the experimental arm with the PI3K inhibitor (predictive potential) (Figure 2). Only trials such as this one will be able to enlighten us on both the prognostic and predictive implications of this common aberration.

\section{Conclusion}

PIK3CA mutations represent one of the most common molecular aberrations in breast cancer. Despite the counterintuitive findings concerning their prognostic significance, active investigation of PI3K pathway blockade is currently ongoing and still could prove to be a curative strategy for PIK3CA mutant breast cancers. Prospective clinical trials selecting patients on the basis of PIK3CA mutations are currently recruiting (Table 2), but upfront stratification will be required in order to ensure enough power is seen in the PIK3CA mutant subgroup. However, there is still much to be learnt about how the mutation contributes to breast cancer growth and, most of all, why high levels of classical PI3K signaling are not observed in human breast cancers. This may be critical to understanding who will respond to therapeutic PI3K inhibition. Recently developed mouse models will help to increase our understanding of cooperating pathways and mammary tumor pathogenesis, as well as immune and stromal influences. Detailed translational research correlative efforts will need to be systematically coupled with clinical trials evaluating efficacy of PI3K inhibitors in breast cancers, as this will enhance our understanding of responders and non-responders by providing the complete genomic

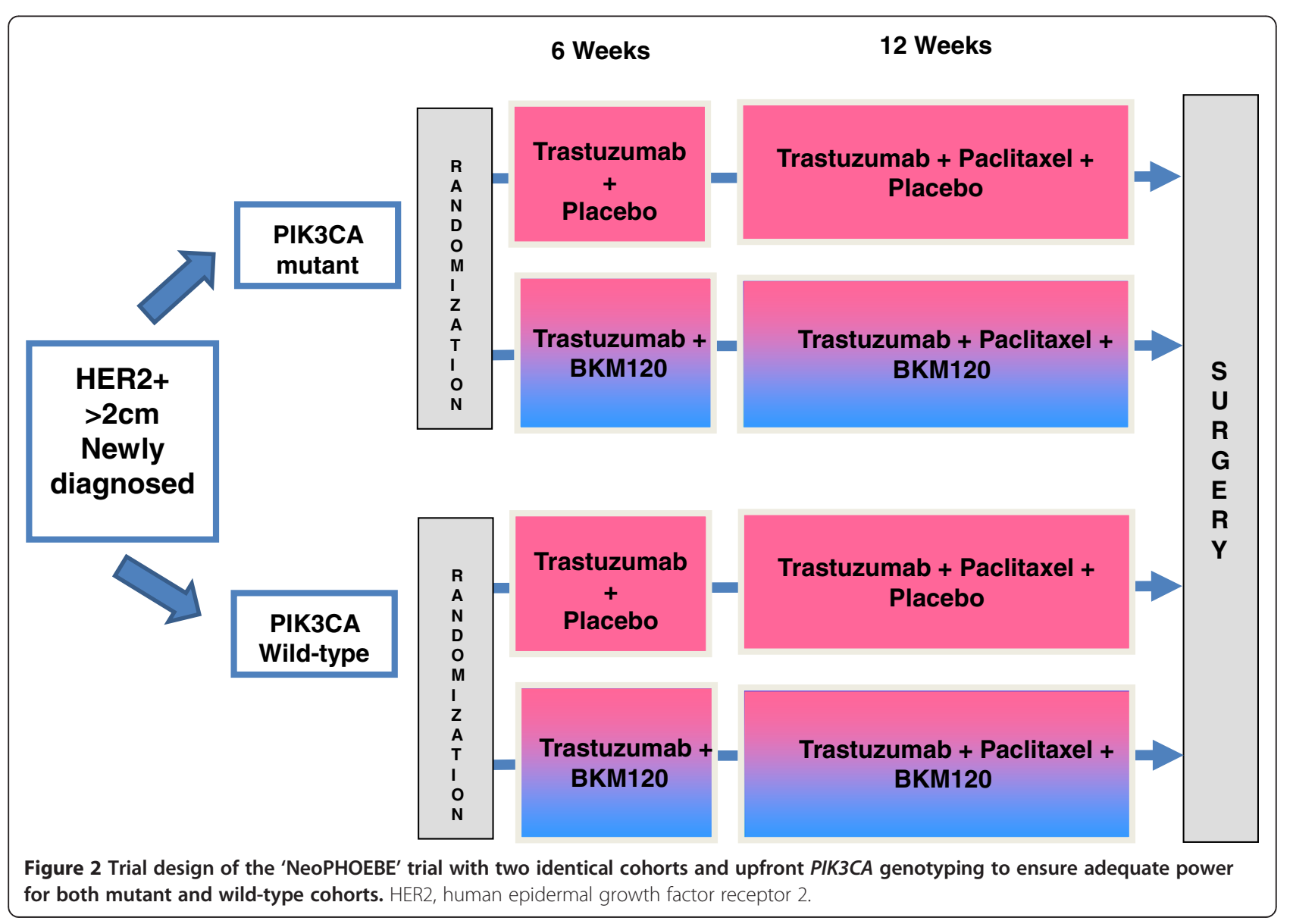


landscape associated with PIK3CA mutations and treatment response.

\section{Abbreviations}

ER: Estrogen receptor; HER2: Human epidermal growth factor receptor 2; MMTV: Mouse mammary tumor virus; mTOR: Mammalian target of rapamycin; PI3K: Phosphoinositide 3-kinase; PTEN: Phosphatase and tensin homologue; RTK: Receptor tyrosine kinase.

\section{Competing interests}

DZ and WAP have no competing interests to declare. A provisional worldwide patent was filed by Université Libre de Bruxelles for PIK3CA mutation gene signature: prognosis and therapeutic responsiveness of HER2 overexpressing and estrogen receptor-positive breast cancer. SL is a named inventor, but receives no financial income. SL has acted as consultant for Novartis but has received no honoraria.

\section{Acknowledgements}

SL is supported by the National Health and Medical Research Council of Australia (NH\&MRC).

\section{Author details}

${ }^{1}$ BrEAST Data Center, Insitut Jules Bordet, 1000 Brussels, Belgium. ${ }^{2}$ Surgical Oncology Research Laboratory, Peter MacCallum Cancer Centre, Melbourne, Victoria 3002, Australia. ${ }^{3}$ Division of Cancer Medicine and Research, Peter MacCallum Cancer Centre, St Andrews Place, East Melbourne, Victoria 3002, Australia. ${ }^{4}$ Sir Peter MacCallum Department of Oncology, University of Melbourne, Parkville, Victoria 3002, Australia.

\section{Published: 23 Jan 2014}

\section{References}

1. Cantley LC: The phosphoinositide 3-kinase pathway. Science 2002, 296:1655-1657.

2. COSMIC: Catalogue of somatic mutations in cancer. [http://cancer.sanger ac.uk/cancergenome/projects/cosmic/]

3. Vanhaesebroeck B, Stephens L, Hawkins P: PI3K signalling: the path to discovery and understanding. Nat Rev Mol Cell Biol 2012, 13:195-203.

4. Engelman JA, Luo J, Cantley LC: The evolution of phosphatidylinositol 3kinases as regulators of growth and metabolism. Nat Rev Genet 2006, 7:606-619.

5. Amzel LM, Huang C-H, Mandelker D, Lengauer C, Gabelli SB, Vogelstein B: Structural comparisons of class I phosphoinositide 3-kinases. Nat Rev Cancer 2008, 8:665-669.

6. Stephens L, Anderson K, Stokoe D, Erdjument-Bromage H, Painter GF, Holmes AB, Gaffney PR, Reese CB, McCormick F, Tempst P, Coadwell J, Hawkins PT: Protein kinase B kinases that mediate phosphatidylinositol 3,4,5-trisphosphate-dependent activation of protein kinase B. Science 1998, 279:710-714

7. Manning BD, Cantley LC: AKT/PKB signaling: navigating downstream. Cell 2007, 129:1261-1274

8. Velho S, Oliveira C, Ferreira A, Ferreira AC, Suriano G, Schwartz S Jr, Duval A, Carneiro F, Machado JC, Hamelin R, Seruca R: The prevalence of PIK3CA mutations in gastric and colon cancer. Eur J Cancer 2005, 41:1649-1654.

9. Lee J, van Hummelen P, Go C, Palescandolo E, Jang J, Park HY, Kang SY, Park JO, Kang WK, MacConaill L, Kim KM: High-throughput mutation profiling identifies frequent somatic mutations in advanced gastric adenocarcinoma. PLoS One 2012, 7:e38892.

10. Spoerke JM, O'Brien C, Huw L, Koeppen H, Fridlyand J, Brachmann RK, Haverty PM, Pandita A, Mohan S, Sampath D, Friedman LS, Ross L, Hampton GM, Amler LC, Shames DS, Lackner MR: Phosphoinositide 3-kinase (PI3K) pathway alterations are associated with histologic subtypes and are predictive of sensitivity to PI3K inhibitors in lung cancer preclinical models. Clin Cancer Res 2012, 18:6771-6783.

11. Gallia GL, Rand V, Siu IM, Eberhart CG, James CD, Marie SK, Oba-Shinjo SM, Carlotti CG, Caballero OL, Simpson AJ, Brock MV, Massion PP, Carson BS Sr, Riggins GJ: PIK3CA gene mutations in pediatric and adult glioblastoma multiforme. Mol Cancer Res 2006, 4:709-714.

12. Krakstad C, Birkeland E, Seidel D, Kusonmano K, Petersen K, Mjøs S, Hoivik EA, Wik E, Halle MK, Øyan AM, Kalland KH, Werner HM, Trovik J, Salvesen H:
High-throughput mutation profiling of primary and metastatic endometrial cancers identifies KRAS, FGFR2 and PIK3CA to be frequently mutated. PLoS One 2012, 7:e52795.

13. Riener M-O, Bawohl M, Clavien P-A, Jochum W: Rare PIK3CA hotspot mutations in carcinomas of the biliary tract. Genes Chromosomes Cancer 2008, 47:363-367.

14. Qiu W, Schönleben F, Li X, Ho DJ, Close LG, Manolidis S, Bennett BP, Su GH: PIK3CA mutations in head and neck squamous cell carcinoma. Clin Cancer Res 2006, 12:1441-1446.

15. Kuo KT, Mao TL, Jones S, Veras E, Ayhan A, Wang TL, Glas R, Slamon D, Velculescu VE, Kuman RJ, Shih IM: Frequent activating mutations of PIK3CA in ovarian clear cell carcinoma. Am J Pathol 2009, 174:1597-1601.

16. Kompier LC, Lurkin I, van der Aa MNM, van Rhijn BWG, van der Kwast $T H$, Zwarthoff EC: FGFR3, HRAS, KRAS, NRAS and PIK3CA mutations in bladder cancer and their potential as biomarkers for surveillance and therapy. PLoS One 2010, 5:e13821.

17. Banerji S, Cibulskis K, Rangel-Escareno C, Brown KK, Carter SL, Frederick AM, Lawrence MS, Sivachenko AY, Sougnez C, Zou L, Cortes ML, FernandezLopez JC, Peng S, Ardlie KG, Auclair D, Bautista-Piña V, Duke F, Francis J, Jung J, Maffuz-Aziz A, Onofrio RC, Parkin M, Pho NH, Quintanar-Jurado V, Ramos AH, Rebollar-Vega R, Rodriguez-Cuevas S, Romero-Cordoba SL, Schumacher SE, Stransky N, et al: Sequence analysis of mutations and translocations across breast cancer subtypes. Nature 2012, 486:405-409.

18. Cancer Genome Atlas Network: Comprehensive molecular portraits of human breast tumours. Nature 2012, 490:61-70.

19. Stephens PJ, Tarpey PS, Davies H, Van Loo P, Greenman C, Wedge DC, Nik-Zainal S, Martin S, Varela I, Bignell GR, Yates LR, Papaemmanuil E, Beare D, Butler A, Cheverton A, Gamble J, Hinton J, Jia M, Jayakumar A, Jones D, Latimer C, Lau KW, McLaren S, McBride DJ, Menzies A, Mudie L, Raine K, Rad R, Chapman MS, Teague J, et al: The landscape of cancer genes and mutational processes in breast cancer. Nature 2012, 486:400-404.

20. Campbell IG, Russell SE, Choong DY, Montgomery KG, Ciavarella ML, Hooi CS, Cristiano BE, Pearson RB, Phillips WA: Mutation of the PIK3CA gene in ovarian and breast cancer. Cancer Res 2004, 64:7678-7681.

21. Samuels Y, Wang Z, Bardelli A, Silliman N, Ptak J, Szabo S, Yan H, Gazdar A Powell SM, Riggins GJ, Willson JK, Markowitz S, Kinzler KW, Vogelstein B, Velculescu VE: High frequency of mutations of the PIK3CA gene in human cancers. Science 2004, 304:554.

22. Samuels Y, Diaz LA Jr, Schmidt-Kittler O, Cummins JM, Delong L, Cheong I, Rago C, Huso DL, Lengauer C, Kinzler KW, Vogelstein B, Velculescu VE: Mutant PIK3CA promotes cell growth and invasion of human cancer cells. Cancer Cell 2005, 7:561-573.

23. Isakoff SJ: Breast cancer-associated PIK3CA mutations are oncogenic in mammary epithelial cells. Cancer Res 2005, 65:10992-11000.

24. Zhao Jj: The oncogenic properties of mutant $\mathrm{p} 110$ and $\mathrm{p} 110$ phosphatidylinositol 3-kinases in human mammary epithelial cells. Proc Natl Acad Sci USA 2005, 102:18443-18448.

25. Kang S: Phosphatidylinositol 3-kinase mutations identified in human cancer are oncogenic. Proc Natl Acad Sci USA 2005, 102:802-807.

26. Bader AG: Cancer-specific mutations in PIK3CA are oncogenic in vivo. Proc Natl Acad Sci USA 2006, 103:1475-1479.

27. Zhao L, Vogt PK: Helical domain and kinase domain mutations in $p 110$ of phosphatidylinositol 3-kinase induce gain of function by different mechanisms. Proc Natl Acad Sci USA 2008, 105:2652-2657.

28. Chaussade C, Cho K, Mawson C, Rewcastle GW, Shepherd PR: Functional differences between two classes of oncogenic mutation in the PIK3CA gene. Biochem Biophys Res Commun 2009, 381:577-581.

29. Pang H, Flinn R, Patsialou A, Wyckoff J, Roussos ET, Wu H, Pozzuto M, Goswami S, Condeelis JS, Bresnick AR, Segall JE, Backer JM: Differential enhancement of breast cancer cell motility and metastasis by helical and kinase domain mutations of class IA phosphoinositide 3-kinase. Cancer Res 2009, 69:8868-8876.

30. Hao Y, Wang C, Cao B, Hirsch BM, Song J, Markowitz SD, Ewing RM, Sedwick D, Liu L, Zheng W, Wang Z: Gain of interaction with IRS1 by p110a-helical domain mutants is crucial for their oncogenic functions. Cancer Cell 2013, 23:583-593

31. Miled N, Yan Y, Hon WC, Perisic O, Zvelebil M, Inbar Y, Schneidman-Duhovny D, Wolfson HJ, Backer JM, Williams RL: Mechanism of two classes of cancer mutations in the phosphoinositide 3-kinase catalytic subunit. Science 2007, 317:239-242. 
32. Huang C-H, Mandelker D, Schmidt-Kittler O, Samuels Y, Velculescu VE, Kinzler KW, Vogelstein B, Gabelli SB, Amzel LM: The structure of a human p110/p85 complex elucidates the effects of oncogenic PI3K mutations. Science 2007, 318:1744-1748.

33. Gymnopoulos M, Elsliger M-A, Vogt PK: Rare cancer-specific mutations in PIK3CA show gain of function. Proc Natl Acad Sci USA 2007, 104:5569-5574.

34. Loi S, Michiels S, Lambrechts D, Fumagalli D, Claes B, Kellokumpu-Lehtinen PL, Bono P, Kataja V, Piccart MJ, Joensuu H, Sotiriou C: Somatic mutation profiling and associations with prognosis and trastuzumab benefit in early breast cancer. J Natl Cancer Inst 2013, 105:960-967.

35. Sabine V, Crozier C, Drake C, Piper T, van de Velde CJ, Hasenburg A, Kieback DG, Markopoulos C, Dirix L, Seynaeve C, Rea D, Bartlett JMS: PIK3CA mutations are linked to PgR expression: A Tamoxifen Exemestane Adjuvant Multinational (TEAM) pathology study. Cancer Res 2012, 72:S1-S5.

36. Aka JA, Adjo Aka J, Lin S-X: Comparison of functional proteomic analyses of human breast cancer cell lines T47D and MCF7. PLoS One 2012, 7: e31532.

37. Berns K, Horlings HM, Hennessy BT, Madiredjo M, Hijmans EM, Beelen K, Linn SC, Gonzalez-Angulo AM, Stemke-Hale K, Hauptmann M, Beijersbergen $\mathrm{RL}$, Mills GB, van de Vijver MJ, Bernards R: A functional genetic approach identifies the PI3K pathway as a major determinant of trastuzumab resistance in breast cancer. Cancer Cell 2007, 12:395-402.

38. Kataoka Y, Mukohara T, Shimada H, Saijo N, Hirai M, Minami H: Association between gain-of-function mutations in PIK3CA and resistance to HER2targeted agents in HER2-amplified breast cancer cell lines. Ann Oncol 2009, 21:255-262.

39. Junttila TT, Akita RW, Parsons K, Fields C, Lewis Phillips GD, Friedman LS, Sampath D, Sliwkowski MX: Ligand-independent HER2/HER3/PI3K complex is disrupted by trastuzumab and is effectively inhibited by the PI3K inhibitor GDC-0941. Cancer Cell 2009, 15:429-440.

40. Zardavas D, Fumagalli D, Loi S: Phosphatidylinositol 3-kinase/AKT/mammalian target of rapamycin pathway inhibition: a breakthrough in the management of luminal (ER+/HER2-) breast cancers? Curr Opin Oncol 2012, 24:623-634.

41. Massarweh S, Osborne CK, Creighton CJ, Qin L, Tsimelzon A, Huang S, Weiss $H$, Rimawi M, Schiff $R$ : Tamoxifen resistance in breast tumors is driven by growth factor receptor signaling with repression of classic estrogen receptor genomic function. Cancer Res 2008, 68:826-833.

42. Juncker-Jensen A, Lykkesfeldt AE, Worm J, Ralfkiaer U, Espelund U, Jepsen $J S$ : Insulin-like growth factor binding protein 2 is a marker for antiestrogen resistant human breast cancer cell lines but is not a major growth regulator. Growth Horm IGF Res 2006, 16:224-239.

43. Miller TW, Hennessy BT, González-Angulo AM, Fox EM, Mills GB, Chen H, Higham C, García-Echeverría C, Shyr Y, Arteaga CL: Hyperactivation of phosphatidylinositol-3 kinase promotes escape from hormone dependence in estrogen receptor-positive human breast cancer. J Clin Invest 2010, 120:2406-2413.

44. Loi S, Haibe-Kains B, Majjaj S, Lallemand F, Durbecq V, Larsimont D, Gonzalez-Angulo AM, Pusztai L, Symmans WF, Bardelli A, Ellis P, Tutt AN, Gillett CE, Hennessy BT, Mills GB, Phillips WA, Piccart MJ, Speed TP, McArthur GA, Sotiriou C: PIK3CA mutations associated with gene signature of low mTORC1 signaling and better outcomes in estrogen receptor-positive breast cancer. Proc Natl Acad Sci USA 2010, 107:10208-10213.

45. Koren S, Bentires-Alj M: Mouse models of PIK3CA mutations: one mutation initiates heterogeneous mammary tumors. FEBS J 2013, 280:2758-2765.

46. Meyer DS, Brinkhaus H, Muller U, Muller M, Cardiff RD, Bentires-Alj M: Luminal expression of PIK3CA mutant H1047R in the mammary gland induces heterogeneous tumors. Cancer Res 2011, 71:4344-4351.

47. Adams JR, Xu K, Liu JC, Agamez NM, Loch AJ, Wong RG, Wang W, Wright $\mathrm{KL}$, Lane TF, Zacksenhaus E, Egan SE: Cooperation between Pik3ca and p53 mutations in mouse mammary tumor formation. Cancer Res 2011, 71:2706-2717.

48. Tikoo A, Roh V, Montgomery KG, Ivetac I, Waring P, Pelzer R, Hare L, Shackleton M, Humbert P, Phillips WA: Physiological levels of Pik3ca (H1047R) mutation in the mouse mammary gland results in ductal hyperplasia and formation of ERa-positive tumors. PLOS One 2012, 7: e36924.

49. Yuan W, Stawiski E, Janakiraman V, Chan E, Durinck S, Edgar KA, Kljavin NM, Rivers CS, Gnad F, Roose-Girma M, Haverty PM, Fedorowicz G, Heldens S, Soriano RH, Zhang Z, Wallin JJ, Johnson L, Merchant M, Modrusan Z, Stern $\mathrm{HM}$, Seshagiri S: Conditional activation of Pik3ca(H1047R) in a knock-in mouse model promotes mammary tumorigenesis and emergence of mutations. Oncogene 2013, 32:318-326.

50. Liu P, Cheng H, Santiago S, Raeder M, Zhang F, Isabella A, Yang J, Semaan DJ, Chen C, Fox EA, Gray NS, Monahan J, Schlegel R, Beroukhim R, Mills GB Zhao JJ: Oncogenic PIK3CA-driven mammary tumors frequently recur via PI3K pathway-dependent and PI3K pathway-independent mechanisms. Nat Med 2011, 17:1116-1120.

51. Kalinsky K, Jacks LM, Heguy A, Patil S, Drobnjak M, Bhanot UK, Hedvat CV, Traina TA, Solit D, Gerald W, Moynahan ME: PIK3CA mutation associates with improved outcome in breast cancer. Clin Cancer Res 2009, 15:5049-5059.

52. Cizkova M, Susini A, Vacher S, Cizeron-Clairac G, Andrieu C, Driouch K,

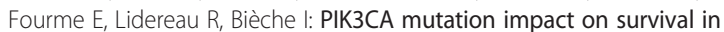
breast cancer patients and in ERa, PR and ERBB2-based subgroups. Breast Cancer Res 2012, 14:R28.

53. Pérez-Tenorio G, Alkhori L, Olsson B, Waltersson MA, Nordenskjöld B, Rutqvist LE, Skoog L, Stål O: PIK3CA mutations and PTEN loss correlate with similar prognostic factors and are not mutually exclusive in breast cancer. Clin Cancer Res 2007, 13:3577-3584.

54. Boyault S, Drouet Y, Navarro C, Bachelot T, Lasset C, Treilleux I, Tabone E, Puisieux A, Wang Q: Mutational characterization of individual breast tumors: TP53 and PI3K pathway genes are frequently and distinctively mutated in different subtypes. Breast Cancer Res Treat 2012, 132:29-39.

55. Joensuu H, Kellokumpu-Lehtinen P-L, Bono P, Alanko T, Kataja V, Asola R, Utriainen T, Kokko R, Hemminki A, Tarkkanen M, Turpeenniemi-Hujanen T, Jyrkkiö S, Flander M, Helle L, Ingalsuo S, Johansson K, Jääskeläinen A-S, Pajunen M, Rauhala M, Kaleva-Kerola J, Salminen T, Leinonen M, Elomaa I, Isola J: Adjuvant docetaxel or vinorelbine with or without trastuzumab for breast cancer. N Engl J Med 2006, 354:809-820.

56. Loi S, Michiels S, Lambrechts D, Fumagalli D, Claes B, Kellokumpu-Lehtinen PL, Bono P, Kataja V, Piccart MJ, Joensuu H, Sotiriou C: Somatic mutation profiling and associations with prognosis and trastuzumab benefit in early breast cancer. J Natl Cancer Inst 2013, 105:960-967.

57. Ellis MJ, Lin L, Crowder R, Tao Y, Hoog J, Snider J, Davies S, DeSchryver K, Evans DB, Steinseifer J, Bandaru R, Liu W, Gardner H, Semiglazov V, Watson M, Hunt K, Olson J, Baselga J: Phosphatidyl-inositol-3-kinase alpha catalytic subunit mutation and response to neoadjuvant endocrine therapy for estrogen receptor positive breast cancer. Breast Cancer Res Treat 2010, 119:379-390.

58. Miron A, Varadi M, Carrasco D, Li H, Luongo L, Kim HJ, Park SY, Cho EY, Lewis G, Kehoe S, Iglehart JD, Dillon D, Allred DC, Macconaill L, Gelman R, Polyak K: PIK3CA mutations in in situ and invasive breast carcinomas. Cancer Res 2010, 70:5674-5678.

59. Stemke-Hale K, Gonzalez-Angulo AM, Lluch A, Neve RM, Kuo WL, Davies M, Carey M, Hu Z, Guan Y, Sahin A, Symmans WF, Pusztai L, Nolden LK, Horlings $H$, Berns K, Hung MC, van de Vijver MJ, Valero V, Gray JW, Bernards R, Mills GB, Hennessy BT: An integrative genomic and proteomic analysis of PIK3CA, PTEN, and AKT mutations in breast cancer. Cancer Res 2008, 68:6084-6091.

60. Carracedo A, Alimonti A, Pandolfi PP: PTEN level in tumor suppression: how much is too little? Cancer Res 2011, 71:629-633.

61. Razis E, Bobos M, Kotoula V, Eleftheraki AG, Kalofonos HP, Pavlakis K, Papakostas P, Aravantinos G, Rigakos G, Efstratiou I, Petraki K, Bafaloukos D, Kostopoulos I, Pectasides D, Kalogeras KT, Skarlos D, Fountzilas G: Evaluation of the association of PIK3CA mutations and PTEN loss with efficacy of trastuzumab therapy in metastatic breast cancer. Breast Cancer Res Treat 2011, 128:447-456.

62. Chandarlapaty S, Sakr RA, Giri D, Patil S, Heguy A, Morrow M, Modi S, Norton L, Rosen N, Hudis C, King TA: Frequent mutational activation of the PI3K-AKT pathway in trastuzumab-resistant breast cancer. Clin Cancer Res 2012, 18:6784-6791.

63. Esteva FJ, Guo H, Zhang S, Santa-Maria C, Stone S, Lanchbury JS, Sahin AA, Hortobagyi GN, Yu D: PTEN, PIK3CA, p-AKT, and p-p70S6K status: association with trastuzumab response and survival in patients with HER2positive metastatic breast cancer. Am J Pathol 2010, 177:1647-1656.

64. Eichhorn PJ, Gili M, Scaltriti M, Serra V, Guzman M, Nijkamp W, Beijersbergen RL, Valero V, Seoane J, Bernards R, Baselga J: Phosphatidylinositol 3-kinase hyperactivation results in lapatinib resistance that is reversed by the mTOR/phosphatidylinositol 3-kinase inhibitor NVP-BEZ235. Cancer Res 2008, 68:9221-9230.

65. Wang L, Zhang Q, Zhang J, Sun S, Guo H, Jia Z, Wang B, Shao Z, Wang Z, Hu X: PI3K pathway activation results in low efficacy of both trastuzumab and lapatinib. BMC Cancer 2011, 11:248. 
66. Baselga J, Cortés J, Kim SB, Im SA, Hegg R, Im YH, Roman L, Pedrini JL, Pienkowski T, Knott A, Clark E, Benyunes MC, Ross G, Swain SM, CLEOPATRA Study Group: Pertuzumab plus trastuzumab plus docetaxel for metastatic breast cancer. N Engl J Med 2012, 366:109-119.

67. Baselga J, Cortes J, Im S-A, Clark E, Kiermaier A, Ross G, Swain SM: Biomarker analyses in CLEOPATRA: a phase III, placebo controlled study of pertuzumab in HER2-positive, first-line metastatic breast cancer (MBC). Cancer Res 2012, 72:S1-S5.

68. Sheppard K, Kinross KM, Solomon B, Pearson RB, Phillips WA: Targeting PI3 kinase/AKT/mTOR signaling in cancer. Crit Rev Oncog 2012, 17:69-95.

69. She QB, Chandarlapaty S, Ye Q, Lobo J, Haskell KM, Leander KR, DeFeoJones D, Huber HE, Rosen N: Breast tumor cells with PI3K mutation or HER2 amplification are selectively addicted to Akt signaling. PLoS One 2008, 3:e3065

70. Crowder RJ, Phommaly C, Tao Y, Hoog J, Luo J, Perou CM, Parker JS, Miller MA, Huntsman DG, Lin L, Snider J, Davies SR, Olson JA Jr, Watson MA, Saporita A, Weber JD, Ellis MJ: PIK3CA and PIK3CB inhibition produce synthetic lethality when combined with estrogen deprivation in estrogen receptor-positive breast cancer. Cancer Res 2009, 69:3955-3962.

71. Jamieson S, Flanagan JU, Kolekar S, Buchanan C, Kendall JD, Lee WJ, Rewcastle GW, Denny WA, Singh R, Dickson J, Baguley BC, Shepherd PR: A drug targeting only p110a can block phosphoinositide 3-kinase signalling and tumour growth in certain cell types. Biochem J 2011, 438:53-62.

72. Juric D, Rodon J, Gonzalez-Angulo AM, Burris HA, Bendell J, Berlin JD, Middleton MR, Bootle D, Boehm M, Schmitt A, Rouyrre N, Quadt C, Baselga J: Abstract CT-01: BYL719, a next generation PI3K alpha specific inhibitor: preliminary safety, PK, and efficacy results from the first-in-human study. Cancer Res 2012, 72:CT-01-CT-01.

73. Mayer I, Abramson V, Balko J, Isakoff SJ, Kuba MG, Sanders ME, Forero-Torres A, Yap JT, Van Den Abbeele AD, Li Y, Arteaga CL, Winer E: SU2C phase lb study of pan-PI3K inhibitor BKM120 with letrozole in ER+/HER2- metastatic breast cancer (MBC). J Clin Oncol 2012, 30:Abstract 510.

74. Krop IE, Saura C, Ahnert J, Becerra C, Britten C, Isakoff SJ, Demanse D, Hackl W, Quadt C, Silva AP, Burris HA, Abu-Khalaf MM, Baselga J: A phase I/IB dose-escalation study of BEZ235 in combination with trastuzumab in patients with PI3-kinase or PTEN altered HER2+ metastatic breast cancer. J Clin Oncol 2012, 30:Abstract 508.

75. Baselga J, Campone M, Piccart M, Burris HA 3rd, Rugo HS, Sahmoud T, Noguchi S, Gnant M, Pritchard KI, Lebrun F, Beck JT, Ito Y, Yardley D, Deleu I, Perez A, Bachelot T, Vittori L, Xu Z, Mukhopadhyay P, Lebwohl D, Hortobagyi GN: Everolimus in postmenopausal hormone-receptorpositive advanced breast cancer. N Engl J Med 2012, 366:520-529.

76. Hortobagyi GN, Piccart MJ, Rugo HS, Burris HA, Campone M, Noguchi S, Perez A, Deleu I, Shtivelband M, Provencher L, Masuda N, Dakhil SR, Anderson I, Chen D, Damask A, Huang A, McDonald R, Taran T, Sahmoud T, Baselga J: Correlation of molecular alterations with efficacy of everolimus in hormone receptor-positive, HER2-negative advanced breast cancer: results from BOLERO-2. 2013 ASCO Annual Meeting. J Clin Oncol 2013, 31:Abstract LBA509.

77. NeoPHOEBE: Neoadjuvant Trastuzumab + BKM120 in Combination With Weekly Paclitaxel in HER2-positive Primary Breast Cancer. [http:// clinicaltrials.gov/ct2/show/NCT01816594]

\subsection{6/bcr3605}

Cite this article as: Zardavas et al:: PIK3CA mutations in breast cancer: reconciling findings from preclinical and clinical data. Breast Cancer Research 2014, 16:201 